\title{
Adverse Effects of Two Kinds of Food Additive Mixtures (Sodium benzoate + Monosodium glutamate, Monosodium glutamate + Chlorophyllin and Sodium benzoate + Chlorophyllin) on Some Physiological Parameters in Male Albino Rats Eman G.E. Helal*1, Mohamed A. Abdelaziz ${ }^{2}$, Nahla S.A. EL-Shenawe ${ }^{1}$ \\ ${ }^{1}$ Department of Zoology, Faculty of Science (Girls), Al-Azhar University, ${ }^{2}$ Physiology Department, Faculty of Medicine, Al -Azhar University, Egypt \\ *Corresponding Author: Eman Helal, Email: emanhelal@azhar.edu.eg, Mobile: 00201001025364, orcid.org/0000-0003-0527-7028
}

\begin{abstract}
Background: Food additives are substances used in food industry in order to improve the food's taste and appearance by preserving its flavor and preventing it from souring.

Materials and Methods: this study was conducted on twenty-four young male albino rats with an average 120-140 g body weight. Animals were divided into four groups (6 each). Group I: Control untreated group, Group II: it was administered sodium benzoate (SB) (5 mg/kg b.w./day) orally and monosodium glutamate (MSG) (15 mg/kg b.w./day), Group III: it was administered MSG (15 mg/kg b.w./day) and chlorophyllin (CHL) (15 mg/kg b.w./day) and Group IV administered orally with SB (5 mg/kg b.w./day) and CHL (15 mg/kg b.w./day). Blood samples were collected on the last day of experiment, for biochemical estimations.

Results: There was marked elevation in levels of fasting glucose, insulin, HOMA-IR, activities of AST and ALT, urea, creatinine, total cholesterol (TC), triglycerides (TG), LDL-C , VLDL, ratios of TC/HDL-C and LDL-C/HDL-C (risk factors) in all treated group. Serum thyroid hormones (T3 and T4) increased in Group III. On the other hand, there was decline in levels of serum total proteins, albumin, testosterone and HDL-C in all treated groups in comparison with the control group. There was a highly significant reduction in the body weight, T3 and T4 in Group IV, while Group II showed highly significant increase in body weight and a highly significant reduction in globulin level as compared to control rats.
\end{abstract}

Conclusion: The use of these compounds must be limited as it resulted in a vehement disturbance in the biochemical parameters.

Keywords: Food Additives, Thyroid hormones, Monosodium Glutamate, Biochemical parameters.

Abbreviation: SB: Sodium benzoate, MSG: Monosodium glutamate, CHL: Chlorophyllin.

\section{INTRODUCTION}

Food additives are products that are added to the basic foodstuffs to improve their appearance, flavor, taste, color, texture, nutritional value and conservation. It plays a vital role in today's abundant and nutritious food supplies. It allows our growing population to enjoy a variety of delicious healthy foods throughout the year. The use of preservatives in the food industry has increased with the advancement of production techniques ${ }^{(\mathbf{1})}$.

Monosodium glutamate (MSG) is a sodium compound of amino acid (glutamic acid) which is the most naturally occurring non-essential amino acid. Monosodium glutamate contains $78 \%$ glutamic acid, $22 \%$ sodium and water. In its pure form, monosodium glutamate is a white crystalline powder described as a "pleasant" taste. It was introduced into the food supply in the 1940's. MSG has a long history of use in food as a flavor enhancer. MSG has a characteristic taste called umami "savory deliciousness". MSG is metabolized in the liver. The liver plays an important role in the metabolism of glutamate to arginine. The average daily intake of MSG is estimated to be 0.3 $1.0 \mathrm{~g}$ in industrialized countries, but it can be higher occasional, depending on the MSG content of individual food items and an individual's taste preferences. MSG is used in both home and restaurant cooking and it is a common component of Asian diets. According to FDA guidelines, MSG cannot be added to baby food, since it is considered unsafe for that age group. Monosodium glutamate is known to elicit toxic effects such as, impairment in memory retention, damages in the hypothalamic neurons, alterations in mitochondrial lipid peroxidation and antioxidant status in different regions of brain and induce hyperphagia leading to obesity ${ }^{(2)}$.

Preservatives that have a very large area of use are the leading chemicals that individuals offer in daily life. So studies looking at the potential toxic effects of preservatives are of great importance today. Some food preservatives previously reported to be toxic to living. Although preservatives play an important role in food safety, many studies have shown that they have toxic and hereditary effects when used for a long time 
(3) . Sodium benzoate at a general optimum concentration of $0.1 \%$ could be used for preservation of such products as soft drinks, fruit drinks, margarine, and certain fish products. The upper limits of benzoate allowable in foods is about $0.1 \%$ for United States of America, while a range 0.15 to $0.25 \%$ had been reported for other countries of the world. For European countries, the limit reported range is from 0.015 to $0.5 \%$. Therefore, sodium benzoate could be assimilated widely by consuming a wide range of food products consumed by man (4). In blood plasma, sodium benzoate has a binding affinity for plasma proteins where it is carried out to different tissues. In the liver, it is metabolized by conjugation with glycine, resulting in the formation of hippuric acid. Since the liver is the principle organ for various metabolic and detoxification reactions, it is important to continue to study the adverse effects, that sodium benzoate may exert on this vital organ ${ }^{(5)}$.

In Egypt, there was an increase in the use of synthetic food colorants in the past few years and additionally there was an uncontrolled use of synthetic colour particularly in food mostly consumed by children. More attention must be focused on the physiological effects of colour additives (6). The present investigation is planned to illustrate the effects of chlorophyllin (CHL), which is a water-soluble mixture of sodium-copper salts of the green plant pigment chlorophyll. It has been used as a coloring agent. The individual response varies not only according to dose, age, gender, nutritional status and genetic factors, but also according to long-term exposure to low doses ${ }^{(7)}$. Although many studies have been carried out to look for toxic effects of the food additives used in the present study in laboratory animals, making considerable progress in understanding its effect in vivo is still controversial. The present study, therefore, aimed to investigate and compare some of the toxic effects and biochemical changes induced by, monosodium glutamate, chlorophyllin, and sodium benzoate in adult male albino rats.

\section{MATERIALS AND METHODS}

Twenty-four young male albino rats (weighing 120-140 g) were used in this study. Animals were housed in stainless steel cages, fed on rat chow and offered water ad libitum. The animals were divided into four equal groups (6 rats each) as follows: The first group (the control) untreated group, the second group was administered sodium benzoate $(5 \mathrm{mg} / \mathrm{kg}$ b.w./day) and monosodium glutamate $(15 \mathrm{mg} / \mathrm{kg}$ b.w./day) orally, the third group was administrated with monosodium glutamate $(15 \mathrm{mg} / \mathrm{kg}$ b.w./day) and chlorophyllin $(15 \mathrm{mg} / \mathrm{kg}$ b.w./day) orally and the fourth group was administrated sodium benzoate (5 $\mathrm{mg} / \mathrm{kg} \quad$ b.w./day) and chlorophyllin (15 mg/kg b.w./day) orally. Body weights were recorded every week. After 30 days of treatment, animals were weighed then decapitated. Blood samples were collected for biochemical parameters. Blood samples were centrifuged for $10 \mathrm{~min}$. at $5000 \mathrm{rpm}$ and supernatant sera were separated for analysis without storage or delay.

\section{Biochemical Examination:}

In the present study, total protein (TP) and albumin concentration were estimated, and then serum globulin concentrations were calculated according to the formula.

Globulin $(\mathrm{g} / \mathrm{dl})=$ total protein $(\mathrm{g} / \mathrm{dl})-$ albumin $(\mathrm{g} / \mathrm{dl})$ :

Aspartate aminotransferase (ASAT) and alanine aminotransferase (ALAT) activities, creatinine, urea, glucose concentrations as well as lipid profile (including total cholesterol, triglycerides and high-density lipoprotein cholesterol) were also determined. Concentrations of testosterone and thyroid hormones (T3 and T4) were measured. All parameters were estimated using BioMerieux SA kits, France. Both ratios of serum albumin/ globulin and albumin/creatinine were determined. However, ratios of TC/HDL (risk factor 1) and LDL/HDL (risk factor 2) were also calculated after calculation of serum LDL-C (low-density lipoprotein cholesterol) and VLDL (very low density lipoprotein cholesterol) using the Friedewald's ${ }^{(8)}$ and Norbert ${ }^{(9)}$ formulas, respectively as following: Friedewald's (8) equation: LDL $(\mathrm{mg} / \mathrm{dl})=\mathrm{TC}-\{\mathrm{HDL}+[\mathrm{TG} / 5]\}$. Norbert (9) equation: $\mathrm{VLDL}=\mathrm{TG} / 5$.

\section{Determination of serum insulin level and HOMA-IR:} By using an ELISA (Enzyme Linked Immunosorbent Assay) kit (U.E Type) for measurement of rat insulin with high sensitivity and rapidly using (Biovendor Research and Diagnostic Product ref.) ${ }^{(10)}$. The approximating equation for insulin resistance, in the early model, used a fasting plasma sample, and was derived by use of the insulin-glucose product, divided by a constant:

HOMA -IR = Glucose mg/dl x Insulin $\mu \mathrm{u} / \mathrm{L} / 405$

Fasting glucose in mass units $\mathrm{mg} / \mathrm{dl}$. IR is insulin resistance. Insulin is given in $\mu \mathrm{u} / \mathrm{L}^{(\mathbf{1 1})}$.

This study was conducted in accordance with ethical procedures and policies approved by animal care and use committee of faculty of science, Al-Azhar University, Cairo,Egypt. The study was approved by the Ethics Board of Al-Azhar University. 
Eman Helal et al.

\section{Statistical analysis}

The results were expressed as mean \pm SEM of the mean. Data were analyzed by one way analysis of variance (ANOVA) and were performed using the Statistical Package for the Social Sciences (SPSS) program, version 25. The Bonferroni test was used as a method to compare significance between groups.

\section{RESULTS}

$\%$ of Body weight change and glucose level:

The percent change in the body weight was highly significant increase $(p<0.01)$ in treated rats that received benzoate with MSG. MSG with chlorophyllin showed insignificant change while treated rats with benzoate and chlorophyllin showed highly significant decrease $(\mathrm{p}<0.01)$ in body weight as compared to control rats (Table 1). On the other hand, glucose level, insulin and HOMA-IR revealed a highly significant increase $(\mathrm{p}<0.01)$ in treated rats that received benzoate with MSG and MSG with chlorophyllin. While rats treated with benzoate and chlorophyllin recorded significant increase $(\mathrm{p}<0.05)$ in glucose level and insulin but in HOMA-IR recorded highly significant increase $(\mathrm{p}<0.01)$ compared to control rats (Table 1).

Table (1): Percentage of body weight change, glucose level, insulin and HOMA-IR in control, (SB+MSG), (MSG+CHL) and $(\mathrm{CHL}+\mathrm{SB})$ treated animals.

\begin{tabular}{|l|l|l|l|l|}
\hline Groups & control & $\begin{array}{l}\text { Sodium benzoate }+ \\
\text { Monosodium } \\
\text { glutamate }\end{array}$ & $\begin{array}{l}\text { Monosodium } \\
\text { glutamate }+ \\
\text { Chlorophyllin }\end{array}$ & $\begin{array}{l}\text { Sodium benzoate+ } \\
\text { Chlorophyllin }\end{array}$ \\
\hline $\begin{array}{l}\text { \% of body weight } \\
\text { change from basal levels }\end{array}$ & $35.78 \pm 0.81$ & $42.11 \pm 1.02^{* *}$ & $36.56 \pm 0.93$ & $31.01 \pm 0.70^{* *}$ \\
\hline$\%$ of change from control & & $18 \%$ & $2 \%$ & $-13 \%$ \\
\hline Glucose $(\mathrm{mg} / \mathrm{dl})$ & $75.41 \pm 2.21$ & $91.03 \pm 0.94^{* *}$ & $87.52 \pm 1.36^{* *}$ & $84.12 \pm 1.75^{*}$ \\
\hline$\%$ of change from control & & $21 \%$ & $16 \%$ & $12 \%$ \\
\hline Insulin $(\mu \mathrm{g} / \mathrm{dl})$ & $4.04 \pm 0.37$ & $5.95 \pm 0.16^{* *}$ & $5.14 \pm 0.11^{*}$ & $5.11 \pm 0.08^{*}$ \\
\hline$\%$ of change from control & & $47 \%$ & $27 \%$ & $26 \%$ \\
\hline HOM-IR & $0.74 \pm 0.07$ & $1.33 \pm 0.03^{* *}$ & $1.10 \pm 0.03^{* *}$ & $1.05 \pm 0.03^{* *}$ \\
\hline$\%$ of change from control & & $80 \%$ & $49 \%$ & $42 \%$ \\
\hline V & & &
\end{tabular}

Values represent mean \pm SE (standard error). ( $\mathrm{P}^{*}<0.05, \mathrm{P}^{* *}<0.01$ as compared to control group).

The results of Protein profile are shown in table 2.

Protein profile: our results showed highly significant decreased $(\mathrm{p}<0.01)$ in serum total proteins and albumin levels in all treated group, while globulin level showed insignificant change in all treated groups except in SB+MSGtreated group where it showed a highly significant decrease $(\mathrm{p}<0.01))$ as compared to control rats. Benzoate + CHL-treated group showed a highly significant decrease $(\mathrm{p}<0.01)$ in Albumin/globulin ratios. While other groups recorded insignificant change as compared to control rats (Table 2).

Table (2): Serum total protein (g/dl), albumin (g/dl), globulin and albumin globulin ratio in control, sodium benzoate, MSG and chlorophyllin-treated animals

\begin{tabular}{|c|c|c|c|c|}
\hline Groups & Control & $\begin{array}{l}\text { Sodium benzoate }+ \\
\text { Monosodium } \\
\text { glutamate }\end{array}$ & $\begin{array}{l}\text { Monosodium } \\
\text { glutamate+ } \\
\text { Chlorophyllin } \\
\end{array}$ & $\begin{array}{l}\text { Sodium benzoate+ } \\
\text { Chlorophyllin }\end{array}$ \\
\hline Total Protein(g/dl) & $6.66 \pm 0.34$ & $4.21 \pm 0.06^{* *}$ & $4.66 \pm 0.07 * *$ & $5.12 \pm 0.02 * *$ \\
\hline$\%$ of change & & $-37 \%$ & $-30 \%$ & $-23 \%$ \\
\hline $\operatorname{Albumin}(\mathrm{g} / \mathrm{dl})$ & $3.82 \pm 0.25$ & $2.23 \pm 0.05 * *$ & $2.47 \pm 0.09 * *$ & $2.52 \pm 0.21 * *$ \\
\hline$\%$ of change & & $-42 \%$ & $-35 \%$ & $-34 \%$ \\
\hline Globulin (g/dl) & $2.83 \pm 0.25$ & $1.98 \pm 0.03 * *$ & $2.19 \pm 0.16$ & $2.59 \pm 0.31$ \\
\hline$\%$ of change & & $-30 \%$ & $-23 \%$ & $-8 \%$ \\
\hline Albumin/Globulin & $1.39 \pm 0.14$ & $1.12 \pm 0.35$ & $1.16 \pm 0.12$ & $0.97 \pm 0.08 *$ \\
\hline$\%$ of change & & $-19 \%$ & $-17 \%$ & $-30 \%$ \\
\hline
\end{tabular}

Liver functions: a highly significant increase in the activities of the AST and ALT enzymes were observed in all rat groups treated with different food additive combinations for 30 days as compared to control rats (Tables 3 ). 
Table (3): ALAT and ASAT activities in control, sodium benzoate, MSG and chlorophyllin-treated animals.

\begin{tabular}{|l|l|l|l|l|}
\hline Groups & Control & $\begin{array}{l}\text { Sodium benzoate }+ \\
\text { Monosodium glutamate }\end{array}$ & $\begin{array}{l}\text { Monosodium } \\
\text { glutamate+ } \\
\text { Chlorophyllin }\end{array}$ & $\begin{array}{l}\text { Sodium benzoate+ } \\
\text { Chlorophyllin }\end{array}$ \\
\hline ALAT (U/l) & $22.98 \pm 1.69$ & $43.08 \pm 0.94 * *$ & $41.06 \pm 0.84 * *$ & $40.51 \pm 1.30^{* *}$ \\
\hline$\%$ of change & & $87 \%$ & $79 \%$ & $76 \%$ \\
\hline ASAT (U/l) & $51.71 \pm 1.48$ & $69.39 \pm 0.84 * *$ & $68.46 \pm 1.7 * *$ & $65.05 \pm 1.78^{* *}$ \\
\hline$\%$ of change & & $34 \%$ & $32 \%$ & $26 \%$ \\
\hline
\end{tabular}

Values represent mean \pm SE (standard error). ( $\mathrm{P}^{* *<0.01}$ as compared to control group).

Lipid profile: the present results showed highly significant increase in TC, TG, LDL, VLDL, ratios of TC/HDL (risk ratio 1) and LDL/HDL (risk ratio 2) accompanied with marked decline in HDL in treated rats as compared to control (Table 4).

Table (4): Changes in total cholesterol (TC), triglyceride (TG), HDL-C, LDL-C, vLDL-C, LDL/HDL ratio and TC/HDL ratio in control, sodium benzoate, MSG and chlorophyllin-treated animals.

\begin{tabular}{|l|l|l|l|l|}
\hline Groups & Control & $\begin{array}{l}\text { Sodium benzoate }+ \\
\text { Monosodium } \\
\text { glutamate }\end{array}$ & $\begin{array}{l}\text { Monosodium } \\
\text { glutamate+ } \\
\text { Chlorophyllin }\end{array}$ & $\begin{array}{l}\text { Sodium benzoate+ } \\
\text { Chlorophyllin }\end{array}$ \\
\hline Total Cholesterol(mg/dl) & $80.00 \pm 1.55$ & $115.52 \pm .89^{* *}$ & $109.24 \pm 1.00^{* *}$ & $93.38 \pm 3.06^{* *}$ \\
\hline \% of change & & $44 \%$ & $37 \%$ & $17 \%$ \\
\hline Triglycerides $(\mathrm{mg} / \mathrm{dl})$ & $75.78 \pm 1.96$ & $120.56 \pm 1.12^{* *}$ & $108.46 \pm 1.33^{* *}$ & $95.75 \pm 2.83^{* *}$ \\
\hline \% of change & & $59 \%$ & $43 \%$ & $26 \%$ \\
\hline HDL-C $(\mathrm{mg} / \mathrm{dl})$ & $43.75 \pm 1.53$ & $22.24 \pm 1.58^{* *}$ & $32.24 \pm 1.55^{* *}$ & $27.80 \pm 0.85^{* *}$ \\
\hline \% of change & & $-49 \%$ & $-26 \%$ & $-36 \%$ \\
\hline LDL-C $(\mathrm{mg} / \mathrm{dl})$ & $21.09 \pm 1.89$ & $69.17 \pm 2.16^{* *}$ & $55.30 \pm 2.13^{* *}$ & $46.43 \pm 1.99^{* *}$ \\
\hline$\%$ of change & & $228 \%$ & $162 \%$ & $120 \%$ \\
\hline vLDL $(\mathrm{mg} / \mathrm{dl})$ & $15.15 \pm 0.39$ & $24.10 \pm 0.22^{* *}$ & $21.68 \pm 0.26^{* *}$ & $19.14 \pm 0.56^{* *}$ \\
\hline$\%$ of change & & $59 \%$ & $43 \%$ & $26 \%$ \\
\hline LDL/HDL & $0.48 \pm 0.05$ & $3.19 \pm 0.31^{* *}$ & $1.73 \pm 0.15^{* *}$ & $1.66 \pm 0.07^{* *}$ \\
\hline$\%$ of change & & $565 \%$ & $260 \%$ & $246 \%$ \\
\hline TC/HDL & $1.83 \pm 0.06$ & $5.30 \pm 0.39^{* *}$ & $3.42 \pm 0.19^{* *}$ & $3.35 \pm 0.08^{* *}$ \\
\hline$\%$ of change & & $190 \%$ & $87 \%$ & $83 \%$ \\
\hline
\end{tabular}

Values represent mean \pm SE (standard error). ( $\mathrm{P}^{* *<0.01}$ as compared to control group).

Kidney functions: the recorded results of renal function parameters are shown in table 5.

Table (5): Serum creatinine and urea levels in control, sodium benzoate, MSG and chlorophyllin-treated animals

\begin{tabular}{|l|l|l|l|l|}
\hline Groups & Control & $\begin{array}{l}\text { Sodium benzoate }+ \\
\text { Monosodium } \\
\text { glutamate }\end{array}$ & $\begin{array}{l}\text { Monosodium glutamate+ } \\
\text { Chlorophyllin }\end{array}$ & $\begin{array}{l}\text { Sodium } \\
\text { benzoate+ } \\
\text { Chlorophyllin }\end{array}$ \\
\hline Creatinine $(\mathrm{mg} / \mathrm{l})$ & $0.91 \pm 0.11$ & $1.82 \pm 0.15^{* *}$ & $1.58 \pm 0.2^{*}$ & $1.57 \pm 0.19^{*}$ \\
\hline$\%$ of change & & $100 \%$ & $74 \%$ & $73 \%$ \\
\hline Urea(mg/dl) & $30.34 \pm 1.98$ & $48.47 \pm 1.01^{* *}$ & $44.63 \pm 1.18^{* *}$ & $39.03 \pm 0.79^{* *}$ \\
\hline$\%$ of change & & $60 \%$ & $47 \%$ & $29 \%$ \\
\hline
\end{tabular}

Values represent mean $\pm \mathrm{SE}$ (standard error). ( $\mathrm{P}^{*}<0.05, \mathrm{P}^{* *<0.01}$ as compared to control group).

Hormones: The results of serum level of testosterone, T3, and T4 are shown in table 6. 
Eman Helal et al.

Table (6): Serum testosterone, T3 and T4 levels in control, sodium benzoate, MSG and chlorophyllin treated animals.

\begin{tabular}{|l|l|l|l|l|}
\hline Groups & Control & $\begin{array}{l}\text { Sodium benzoate }+ \\
\text { Monosodium } \\
\text { glutamate }\end{array}$ & $\begin{array}{l}\text { Monosodium } \\
\text { glutamate+ } \\
\text { Chlorophyllin }\end{array}$ & $\begin{array}{l}\text { Sodium benzoate+ } \\
\text { Chlorophyllin }\end{array}$ \\
\hline Testosterone(ng/dl) & $57.30 \pm 2.14$ & $42.41 \pm 0.86^{* *}$ & $45.21 \pm 2.10^{* *}$ & $50.96 \pm 1.06^{*}$ \\
\hline$\%$ of change & & $-26 \%$ & $-21 \%$ & $-11 \%$ \\
\hline T3(ng/dl) & $108.22 \pm 2.27$ & $110.62 \pm 2.74$ & $118.20 \pm 0.77 * *$ & $93.74 \pm 1.22^{* *}$ \\
\hline$\%$ of change & & $2 \%$ & $9 \%$ & $-13 \%$ \\
\hline T4(ng/dl) & $4.57 \pm 0.45$ & $4.29 \pm 0.08$ & $6.20 \pm 0.1 * *$ & $3.29 \pm 0.15^{*}$ \\
\hline$\%$ of change & & $-6 \%$ & $36 \%$ & $-28 \%$ \\
\hline
\end{tabular}

Values represent mean $\pm \mathrm{SE}$ (standard error). ( $\mathrm{P}^{*}<0.05, \mathrm{P}^{* *}<0.01$ as compared to control group).

\section{DISCUSSION}

In the present work, rats treated with mixture of SB + MSG showed highly significant increase in body weight as compared to control group throughout the experimental periods. This might be attributed to MSG intake that could induce an increase in energy intake, which could lead to obesity or alter the levels of carbohydrates, lipids and proteins in rats ${ }^{(\mathbf{1 2})}$. While MSG+CHL showed no change on body weight due to antagonistic effects of both MSG and CHL where MSG induces increase in body weight and CHL induces decrease in body weight. On the other side, the present investigation revealed that rats treated by SB accompanied with CHL for 30 days showed highly significant decrease in body weight as compared to control ones. This may be attributed to synthetic food colorants which cause a significant decrease in body weight. Similar findings were also recorded in rats ${ }^{(\mathbf{1 3}}$, 14).

Furthermore, oral administration with the mixtures of food additives MSG with SB and MSG with CHL to young male albino rats for 30 days showed highly significant increase of fasting blood glucose level, insulin and HOMA-IR in comparison with control rats. The increased blood glucose level following MSG administration was attributed to increased gluconeogenesis from glutamate and glutamine ${ }^{(\mathbf{1 5})}$. Abnormal glucose tolerance could be attributed to decreased cellular insulin sensitivity even under conditions of hyperinsulinemia observed in animals treated with MSG. Under conditions of hyperinsulinemia, cells could switch to pathways that favor gluconeogenesis to compensate for the increased insulin release. MSG administration could not alter the tissue glycogen concentration but increased the activity of glucoce-6-phosphatase while decreased the activity of glucose-6-phosphate dehydrogenase, which could be a response to hyperinsulinemia associated with MSG intake. This observation also shows that glycogenolysis does not play a role in renal glucose regulation. However, in situations where hyperinsulinemia and decreased insulin sensitivity occur simultaneously, the entrance of glucose into the cells diminishes and could lead to increased cellular glucose concentration. Decreased insulin sensitivity in MSG-treated animals under conditions of hyperinsulinemia was attributed to decreased expression of glucose transporter-4 (GLUT4) proteins and insulin receptors ${ }^{(16)}$. Thus, by promoting gluconeogenesis, MSG intake would increase the tissue glucose concentration and eventually lead to hyperglycemia. Hyperglycemia increases glucose autoxidation and the glycation of proteins ${ }^{(17)}$. In addition to increasing the glucose level and the possible autoxidation of glucose that would eventually contribute to oxidative stress, the increased activity of glucose- 6 phosphatase and decreased activity of glucose-6-phosphate dehydrogenase would also cause decrease in influx of glucose-6-phosphate into the pentose phosphate pathway. Consequently, there would be a decreased generation of NADPH needed for the regeneration of glutathione and other reducing agents needed for the maintenance of tissue integrity and oxidative balance. This shows a possible relationship between oxidative stress and altered glucose metabolism and might contribute to the increased renal oxidative stress in MSG-treated rats. MSG administration could therefore deplete the generation of reducing potentials required for the maintenance of tissue integrity, thus increasing the oxidative burden of the tissues ${ }^{(\mathbf{1 8})}$.

Sodium benzoate may play a role in enhancing pancreatic secretions and glycogen metabolism or gluconeogenesis, hence glucose mobilization to the blood. The elevation in the level of glucose can result in peroxidation of membrane lipids by increasing the 
events responsible for glucose oxidation which in turn promotes formation of thiobarbituric acid reactive substances (TBARS), in the presence of cytochrome $\mathrm{P} 450^{(1)}$.

On the other hand, oral administration of food additives MSG, SB and CHL for 30 days showed significant marked decline in the serum total proteins, albumin and albumin/globulin as compared to the corresponding controls. This may be due to stimulation of thyroid and adrenal glands by MSG, which lead to a blocked protein synthesis, fast break down, increased rate of free amino acids and decreased protein turnover ${ }^{(19)}$. Yousef et al. (20) indicated the inhibitory effect of some food additives on the biosynthesis of protein and albumin, which in turn reflects impairment in liver functions. Furthermore, reductions of protein profile in all treated groups can reflect the liver condition that cause hepatotoxicity and liver damage, which lead to inability of liver to produce proteins and causing utilization of amino acids for the oxidation or gluconeogenesis ${ }^{(21)}$.

Liver is the primary site of the synthesis of plasma proteins. A disturbance of protein synthesis therefore occurs because of impaired hepatic function, which would lead to a decrease in their plasma concentration (22). The reduction of the protein concentration in the monosodium glutamate-treated rats could indicate a reduction in the synthetic function of the liver or increase rate of protein degradation ${ }^{(23)}$.

The increase in serum level of ALT and AST as observed in groups induced with these additives may reflect damage of liver cells and cellular degeneration or destruction in this organ, which might be due to the increased permeability of plasma membrane or cellular necrosis. When the liver cell membrane is damaged, varieties of enzymes normally located in the cytosol are released into the blood stream. Elevation of AST and ALT indicates the utilization of amino acids for the oxidation or for gluconeogenesis. These tests are used to determine liver damage and cell necrosis due to toxicity ${ }^{(24)}$. Mahmoud et al. reported that after oral ingestion of benzoic acid and sodium benzoate in experimental animals or humans, there was rapid absorption of the undissociated benzoic acid from the gastrointestinal tract. The substances are metabolized in the liver mainly by conjugation with glycine, resulting in the formation of hippuric acid, which is rapidly excreted via the urine ${ }^{(25)}$. Sodium benzoate caused derangement of liver function as revealed by significant elevation of serum ALT and AST as well as significant reduction of these enzymes in the liver. Determination of AST and ALT in the serum is largely used in the assessment of liver damage. Membrane damage causes the liver to releases the enzymes into circulation and hence could be measured in the serum. High level of serum AST and ALT indicates liver damage (26).

MSG dissociates easily to release free glutamate. The diminution of GLU produces ammonium ion $\left(\mathrm{NH}^{+4}\right)$ that could be toxic unless detoxified in the liver via the reactions of the urea cycle. Thus, the possible ammonium ion overload that may occur as a result of an increased level of glutamate following MSG intake could damage the liver, consequently releasing the ALT enzyme that may lead to its observed elevation. This increase could also be explained by free radical production which reacts with polyunsaturated fatty acids of cell membrane leading to impairment of mitochondrial and plasma membranes resulting in enzyme leakage ${ }^{(27,28)}$.

The significant increase in the activities of serum AST and ALT in rats treated with chlorophyll, may be due to the haptic potency of these colour resulting in destructive changes in the hepatic cells. The colour were administered orally and, hence, they reach the liver first through the portal vein. The effect of the colorant on the liver is in accordance with Helal $\boldsymbol{e t}$ al. ${ }^{(6)}$ who recorded a pronounced increase of serum and liver transaminases activity in rats that ingested synthetic colorants.

Hareeri et al, suggested that disorders of lipid metabolism, hyperlipidemia and obesity are associated with overproduction of oxygen free radicals. The enhanced accumulation of these free radicals and dysfunction of antioxidant defense system resulted in oxidative stress. These radicals can bind covalently to the macromolecules and induce peroxidative degradation of the membrane lipids rich in polyunsaturated fatty acids. Thus, leading to the formation of lipid peroxides followed by multiple pathological changes. Remarkably, this study also revealed that rats orally administrated food additives $\mathrm{SA}+\mathrm{MSG}, \mathrm{CHL}+\mathrm{MSG}$ and $\mathrm{SB}+\mathrm{CHL}$ showed significant increase in total cholesterol, triglycerides, LDL-C and vLDL-C levels, while HDL-C concentration showed a reduction in its level when compared to control rats. MSG increases the synthesis of fatty acids and triglycerides from acetate. This could be due to the transport of acetate into the liver cells, resulting in increased substrate (acetate) availability. MSG intake also increases synthesis of cholesterol. Another reason, that monosodium glutamate was able to increase the activities of 3hydroxyl-3- methylglutaryl coenzyme A (HMG Co A) reductase, the rate limiting enzyme in cholesterol 
Eman Helal et al.

biosynthesis resulting in increased synthesis of cholesterol in the MSG-treated rats. Hyperlipidemia with significantly elevated levels of serum triacylglycerol and cholesterol in monosodium glutamate-treated rats, proposed that a shift in glucose metabolism towards lipogenesis might account for the hyperlipidemia. HDL and LDL are two of the four main groups of plasma lipoproteins that are involved in lipid metabolism and the exchange of cholesterol, cholesterol ester and triglycerides between tissues ${ }^{(29)}$.

These effects of sodium benzoate on the lipid profile might be due to imbalance between normal rates of fat metabolism and secretion. The possible explanation of these observed increments may reside in the direct or indirect action of these food additives on lipid metabolism or lipid peroxidation. The effect of sodium benzoate on lipid profile and their increasing effect on cholesterol concentration in the present study might be an indication of membrane structure and function disruption, thus influence its fluidity, permeability, activity of associated enzymes and transport system ${ }^{(\mathbf{1})}$.

On the other hand, our results demonstrated that the daily intake of food additives MSG and SB, MSG and CHL and SB and CHL exhibited an increase in serum creatinine and urea levels when compared to the control group. It is believed that the significant elevation in urea and creatinine levels is closely related to the impairment of renal function. Bodnar $\boldsymbol{e t}$ al. ${ }^{(30)}$ recorded increased concentrations of creatinine and total urea in blood during renal diseases or renal damage that may be due to high activities of xanthine oxidase, lipid peroxidation and increased triacylglycerol and cholesterol levels, as well as impairment of the urea cycle enzyme activities. Increased concentration of xanthine oxidase was previously reported in rats injected with MSG. Therefore, these impairments could also be attributed to the changes in the threshold of tubular reabsorption, renal blood flow and glomerular filtration rate (GFR) ${ }^{(30)}$. MSG and sodium benzoate might either interfere with creatinine metabolism leading to increased synthesis or the tissues might have compromised all or part of its functional capacity of tubular excretion (31).

Noteworthy, the current study reported that rats treated with SB and MSG, MSG and CHL and SB and CHL showed a highly significant reduction in testosterone hormone levels as compared to control level. Therefore, this reduction in serum testosterone levels may be because of disruption of the hypothalamic-pituitary-testes regulatory axis that controls testosterone production by testicular Leydig cells. This proposition is supported by the reports of previous authors who stated that administration of monosodium glutamate destroys neurons of the hypothalamus in rats and mice. Moreover, this result may be due to reduced gonadotropin-releasing hormone $(\mathrm{GnRH})$ associated with the lesions on the arcuate nucleus of the hypothalamus that occurs in animals given MSG. Such neuronal losses in the hypothalamus can result in disruption of the hypothalamic-pituitary-testes regulatory axis ${ }^{(32)}$.

Hadi and Mehdi (33) illustrated that sodium benzoate leads to decreased production of testicular lipid hormone and lutein. The decrease in the production of lutein hormone contributes to the reduction of building lipid hormone testosterone by inhibiting the genetic expression of the protein StAR, which is one of the most important proteins that are responsible for transfer of cholesterol to the internal membrane in the mitochondria, which uses enzymes that contribute to the formation of steroids. The decrease in lutein secretion also inhibits the enzymes that contribute to the formation of steroids. The stimulation of the hypothalamic-adrenal axis (the primary epithelial system activated in the lobes) by the effect of stress leads to inhibition of the hypothalamicpituitary-hypothalamic axis by inhibiting the secretion of gonadotropin-releasing hormone $(\mathrm{GnRH})$, where male reproductive functions start hormonal control from the hypothalamus region. When this protein reaches the frontal lobe of the pituitary gland, it stimulates the secretion of two hormones, $\mathrm{LH}$ and follicle-stimulating hormone (FSH). These hormones, in addition to other hormones, have to be present for the emergence of spermatozoa process.

Moreover in the present study, it was found that the oral administration of food additives MSG and SB recorded no significant change in T3 and T4 because MSG induced increase in thyroid hormones while SB decreased these hormones. So, both has antagonistic effect. MSG and CHL showed increase in concentrations of thyroid hormones (T3 and T4). These changes in thyroid hormones might be resulting from alteration in the pituitary-thyroid axis. This might play a role in children hyperactivity probably through affecting higher centers in the brain ${ }^{(\mathbf{3 4})}$. It was documented that MSG causes endocrine disorder as a result for induced oxidative stress in experimental animals. On other hand, the oral administration of food additive mixtures $\mathrm{CHL}$ and $\mathrm{SB}$ recorded reduction in $\mathrm{T} 3$ and $\mathrm{T} 4$ due to sodium benzoate, which causes oxidative stress on thyroid function. Alfallouji et al. ${ }^{(35)}$ suggests that hypothyroidism syndrome is associated with an overall increase in oxidative stress. Other than the decrease in thyroid function due to oxidative stress, loss of thyroid hormone-binding 
proteins in urine could be another cause of the decrease in serum T3 and T4 levels. Helal et al. ${ }^{(31)}$ showed that this oxidative stress is due to treatment with sodium benzoate.

\section{CONCLUSION}

Our study demonstrated that oral administration of mixtures of different types of food additive resulted in a vehement disturbance in all studied biochemical parameters including glucose, total protein (TP), albumin, creatinine, urea, activities of AST and ALT in addition to lipid profile by inducing metabolic alterations. The most grievous effects of these food additives reside in its hormonal effect that was pronounced on testosterone and thyroid hormones that can lead to fertility problems and hyperthyroidism, respectively. So, due to the hazardous effects of food additives, it is recommended to limit their uses.

\section{REFERENCES}

1-Tawfek N, Amin H, Abdalla A et al. (2015): Adverse effects of some food additives in adult male albino rats. Current Science International, 4 (4): 525-537.

2-Hareeri N A, Alrasheedi A A, Eassaw MM (2017): Effect of sesame on liver enzymes and lipid profile inrats exposed to oxidative stress induced by Monosodium glutamate. J Nutr Food Sci. , 7:5.

3-Bakar E, Aktac T (2014): Effects of sodium benzoate and citric acid on serum, liver and kidney tissue total sialic acid levels: An ultrastructural study. J Appl Biol Sci., 8 (2): 9-15.

4-Sixtus E, Augustine A, Michael O (2007): In vivo effects of sodium benzoate on plasma aspartate amino transferase and alkaline phosphatase of wistar albino rats. Scientific Research and Essays, 2 (1): 010-012.

5-Aziz I A, Zabut BM (2012): Blood indices of sodiumbenzoate-administrated albino rats: effect of olive oil and/or time-dependent recovery. Egyptian Journal of Biology, 14: 50-56.

6-Helal EG, Zaahkouk SA, Mekkawy HA (2000): Effect of some food colorants (synthetic and natural products) of young albino rats. I-Liver and kidney functions. The Egyptian Journal of Hospital Medicine, 1: 103-113.

7-Amin KA, Hameid H A, Elsttar, A A (2010): Effect of food azo dyes tartrazine and carmoisine on biochemical parameters related to renal, hepatic function and oxidative stress biomarkers in young male rats. Food and Chemical Toxicology, 48 (10): 2994-2999.

8-Friedewald W T, Levy R I, Fredrickson D S (1972): Estimation of the concentration of low-density lipoprotein cholesterol in plasma, without use of the preparative ultracentrifuge. Clinical chemistry, 18: 499-502.

9-Norbert W T (1995): Clinical guide to laboratory tests. 3rd ed. Saunders W. B., Company, Philadelphi.
10-Reeves WG (1983): Insulin antibody determination: Theoretical and practical consideration. Diabetologia, 24: 339-403

11-Matthews DR, Hosker JP,Rudenski AS, Treacher DF et al. (1985): Homeostasis model assessment :insulin resistance and beta cell function from fasting plasma glucose and insulin concentration in man. Diabetologia, 28: 412-419.

12- Mozes Z, Sefcikova L, Lenharde et al. (2004): Obesity and Changes of Alkaline Phosphatase Activity in the Small Intestine of 40-80-Day Old Subjects to Early Postnatal Overfeeding of Monosodium Glutamate. Physiological Research, 53: 177-186.

13- Booth J (1993): Food intolerence in a child with urticaria. J. Human Nutrition and Diebetics, 6 (4): 377-380 14- Brozelleca JF, Olson JW, Reno FE (1989): Life time toxicity/carcinogenicity study of FD \& C red no. 40 (Allura Red) in Sprague - Dawley rats. Fd Chem Toxic., 27 (11): 701-706.

15-Okwudiri O O, Sylvanus A C, Peace I A (2012). Monosodium glutamate induces oxidative stress and affects glucose metabolism in the kidney of rats. International Journal of Biochemistry Research \& Review, 2 (1): 1.

16-Macho L, Ficková M, Ježová D, Zórad Š (2000): Late effects of postnatal administration of monosodium glutamate on insulin action in adult rats. Physiol. Res., 49 (1): S79-S85.

17- Kakkar R, Mantha S V, Radhi J, Prasad K, Kalra J (1997): Antioxidant defense system in diabetic kidney: a time course study. Life sciences, 60 (9): 667-679.

18- Oyewole OI, Dere F A, Okoro O E (2012): Sodium benzoate mediated hepatorenal toxicity in wistar rat: Modulatory effects of azadirachta indica (neem) leaf. European Journal of Medicinal Plants, 2 (1): 11.

19- Abdeen AM, El-Shayeb AF, Othman AI et al. (2008): Histopathological and histochemical studies of the influence of garlic oil against sodium nitriteinduced toxicity in the liver and lungs of albino rat. J Egypt Ger Soc Zool., 55: 261-287.

20. Yousef MI, Omar SA, El-Guendi MI et al. (2010):Potential protective effects of quercetin and curcumin on paracetamol-induced histological changes, oxidative stress, impaired liver and kidney functions and haematotoxicity in rat. Food Chem Toxicol., 48: 3246-3261 21. Etim OE, Farombi EO, Usoh IF et al. (2006): The protective effect of aloevera juice on lindane induced hepatotoxcity and genotoxicity. J Pharmaceut Sci., 19: 337340.

22-Keith G, Tolman MD, Robert R (1999): Liver function. In: Textbook of Clinical Chemistry, 3rd edition, (Burtis CA, Ashwood ER, editors). WB Saunders Company: Philadelphia, Pp: 52-53.

23-Okediran B S, Olurotimi A E, Rahman SA et al. (2014): Alterations in the lipid profile and liver enzymes of rats treated with monosodium glutamate. Sokoto journal of veterinary sciences, 12 (3): 42-46.

24- Ahmed MHM (2016): Effect of some Food Additives Consumption on the Body Weight and Toxicity and the 


\section{Eman Helal et al.}

Possible Ameliorative Role of Green Tea Extract. Middle East Journal of Applied Sciences, 6 (4): 716-730

25- Hassan MM, Abdelgadir MIA et al. (2016): Impacts of the food additive benzoic acid on liver function of wistar rats. Int J Adv Res., 4(8): 568-575.

26-Oyewole O I, Dere F A, Okoro O E (2012): Sodium benzoate mediated hepatorenal toxicity in wistar rat: Modulatory effects of azadirachta indica (neem) leaf. European Journal of Medicinal Plants, 2 (1): 11-17.

27-Tawfik MS, Al-Badr N (2012):Adverse Effects of Monosodium Glutamate on Liver and Kidney Functions in Adult Rats and Potential Protective Effect of Vitamins C and E. Food and Nutrition Sciences, 3 (5): 651- 659.

28-Akanya HO, Peter S, Ossamulu I F, Oibiokpa F I et al. (2015): Evaluation of the change in some liver function and haematological parameters in MSG fed rats. International Journal of Biochemistry Research and Review, 6: 113-120

29- Hareeri NA, Alrasheedi A A ,Eassaw MM (2017): On liver enzymes and lipid profile in rats exposed to oxidative stress induced by Monosodium glutamate. Journal of American Science, 13 (1):71-78 .

30-Bodnar I, Gooz P, Okamura H et al. (2001): Effect of neonatal treatment with monosodium glutamate on dopaminergic and L-DOPA-ergic neurons of the medial basal hypothalamus and on prolactin and MSH secretion of rats. Brain Research Bulletin, 55: 767-774.

31-Helal E G, Barayan A W, Abdelaziz M A, ELShenawe N S (2019): Adverse Effects of Mono Sodium Glutamate, Sodium Benzoate and Chlorophyllins on some Physiological Parameters in Male Albino Rats. Egyptian Journal of Hospital Medicine, 74 (8): 1857-1864.

32-Helal EG, El-Sayed R A, Mustafa M A, El-Gamal M $S$ (2017): Adverse effects of two kinds of food additive mixtures (flavor enhancer, food preservative or food coloring agent) on physiological parameters in young male albino rats. The Egyptian Journal of Hospital Medicine, 67 (1): 344- 351 .

33-Hadi M M, Mahdi W T (2019): The effect of sodium benzoate as a preservative on the reproductive system of male rats. International Journal of Research in Pharmaceutical Sciences, 10(1): 98-105.

34. Helal EG (2001): Progressive effects of the interaction of Sodium nitrite and sunset yellow on different physiological parameters in albino rats. The Egyptian Journal of Hospital Medicine, 2: 23 - 46.

35-Alfallouji S, Ali R K, Ali W J (2012): The Correlation between Oxidative Stress and Thyroid Hormones in Serum and Tissue Homogenized of Hypothyroidism Patients. Medical Journal of Babylon, 9 (4): 843-849. 